\title{
Thirty Years of Research on the Holodomor: A Balance Sheet
}

\author{
Frank Sysyn \\ University of Alberta
}

\begin{abstract}
A preface to the articles of this issue, surveying the role of the Harvard Ukrainian Research Institute in the early phase of Holodomor Studies as well as responses to Robert Conquest's The Harvest of Sorrow: Soviet Collectivization and the Terror-Famine.
\end{abstract}

Keywords: Holodomor Studies, Harvard Ukrainian Research Institute, Robert Conquest

Tn the 1980s the Ukrainian Research Institute at Harvard University (HURI), with which I was then associated, was preoccupied with the Harvard Project in Commemoration of the Millennium of Christianity in Rus'-Ukraine and the Harvard Famine Project, both marking anniversaries (Kohut and Andriewsky 13-16). In the second half of that decade, the thousandth anniversary of the Christianization of Rus'-Ukraine in 1988 engendered a broad agenda of research and publication. The director of HURI, Professor Omeljan Pritsak, and long-time associate director, Professor Ihor Ševčenko, had already made the Institute and its journal Harvard Ukrainian Studies (founded in 1977) leaders in the study of medieval Rus'. They were well disposed to answer the requests of the Ukrainian community and the Ukrainian Studies Fund, which raised funds on behalf of the Institute, that the Institute take an active role in marking this momentous event. At a time when no independent Ukrainian state existed and Ukrainian churches, Catholic and Orthodox, were banned in Ukraine, the marking of the Millennium of the Baptism inevitably had a political dimension. At mid-decade it was clear that the Russian Orthodox Church would centre any commemorations in Moscow, not Kyiv, and that many scholars in the West, not to speak of the media, would treat this event as the Christianization of "Russia." Already in 1984, the Ukrainian Studies Fund began a project to reprint and disseminate scholarly articles dealing with Ukrainian religious and cultural history. Professors Pritsak and Ševčenko conceived a project, beginning in 1987, to publish the original texts and translations of medieval and early modern Ukrainian religious culture in the Harvard Library of Early Ukrainian Literature (20 volumes to 
date). They also planned an international scholarly congress in Ravenna, Italy in 1988 that resulted in one of the most important publications of papers associated with the commemoration (Harvard Ukrainian Studies 1213 [1988-89]). When the Millennium projects were planned in the mid1980s no one could have conceived that by the time of the anniversary, glasnost and perestroika would occur. These changes in the Soviet Union in many ways only sharpened national and religious debates over the significance of the Christianization; they occurred before Ukrainian independence and the restoration of the Ukrainian churches permitted scholars and churchmen in Ukraine to take full part in discussions.

In 1980, as the fiftieth anniversary of the Ukrainian Famine approached, no glimmerings of change in the Soviet Union were in sight. Soviet authorities still denied that any famine had occurred, much less the magnitude of the loss of life it caused. At the same time, the Ukrainian refugees in the West, who were the only group that could bear witness to the tragedy, were aging. I have elsewhere discussed the various projects that put the Ukrainian Famine on the public agenda in North America and Europe in the 1980s, including the film Harvest of Despair, the United States Congress Commission on the Ukraine Famine, the International Commission of Inquiry into the 1932-33 Famine in Ukraine, and the first major scholarly conference, held in 1983 in Montreal (Sysyn). Here let me confine myself to the perspective at HURI and the impact of the Harvard Famine Project on the scholarly community.

Until the early 1980s, the Institute had concentrated on medieval and early modern studies, though the Harvard Committee on Ukrainian Studies included the prominent modern history and politics specialists Richard Pipes and Adam Ulam. Then in early 1980 the Ukrainian Studies Fund requested that the Institute mark the anniversary of the Ukrainian Famine in 1982-83 with appropriate scholarly projects. The Ukrainian Famine Project was initiated in 1980, and in 1981 Dr. James Mace, a recent Ph.D. from the University of Michigan, joined the Institute staff to carry on research on the Famine at Harvard. By mid-1981 the Institute, on the recommendation of Adam Ulam, had reached an agreement with Dr. Robert Conquest to write a monograph on the Famine, for which Dr. Mace was to provide major research assistance. The Soviet authorities took note of this activity, and in 1981 a delegation from the U.N. mission of the Ukrainian Soviet Socialist Republic led by Ivan Khmil' of the Institute of History of the Academy of Sciences of the Ukrainian SSR visited the Institute and tried to get the Institute to abandon this project in return for access to Soviet 
archives and libraries. ${ }^{1}$ In 1983 the Institute organized an exhibition on the Famine at Widener Library that was later published in catalogue form (Procyk et al.). James Mace's first article on the Famine appeared in 1984 (Mace), and he and Robert Conquest were among the authors of a booklet titled The Man-Made Famine in Ukraine, published by the American Enterprise Institute that year.

The much-anticipated monograph by Robert Conquest, The Harvest of Sorrow: Soviet Collectivization and the Terror-Famine, appeared in 1986. The book was sweeping in scope. Conquest dealt with Communist ideology and its relationship to the peasantry before tackling Soviet policies leading up to collectivization and the designation and deportation of kulaks. In emphasizing the role of Stalin, Conquest took a stand in the discussions of the 1980s between the totalitarian school and the revisionists, firmly on the side of the former. Conquest interwove his account with discussions of the nationality issue and religious affairs in the Soviet Union, with special attention to Ukraine. Turning to famine, Conquest wrote one of the first examinations on Central Asia and the mass mortality of the Kazakh Famine of 1931-32. He then discussed the Soviet attack on "Ukrainian nationalism" before turning to the Famine in Ukraine. His graphic depiction of the tragedy used eyewitness testimony. While he confined the use of the term "genocidal" to Ukraine, he also dealt with the famines in the Kuban, the Don region, and the Volga regions, pointing out the large number of Ukrainians and other non-Russian groups there. He used the available evidence to estimate the number of Famine deaths, giving 5 million of 7 million deaths as occurring in Ukraine. He went on to discuss the record of the West in largely not responding to reports of the Famine and, in the case of some reporters, covering it up. Finally he addressed the question of culpability, laying it at the door of Stalin and the regime that had set impossibly high grain requisition quotas and seized foodstuffs, aware that these actions would result in mass starvation-and then tried to cover up the crime. The book had addressed almost all the major issues related to the Famine, interwar Soviet Ukraine, and the Stalinist period. As such it touched on numerous questions and debates in academic as well as political circles.

The book's British (Hutchison) and American (Oxford University Press) publishers and Conquest's renown as a non-fiction writer ensured that the

\footnotetext{
1 This assertion is based on this author's presence at the meeting. For Khmil"s later discussion of the visit and his recounting a conversation with James Mace (see Khmil'). Khmil"s article demonstrates the level of his antagonism to the project, even after he had to admit that the Soviet denial of the Famine was a falsehood.
} 
book was reviewed widely, and not only in academic journals. In Canada, the University of Alberta Press published the book in association with the Canadian Institute of Ukrainian Studies (a list of reviews is appended at the end of this preface). No book dealing with Ukraine had ever received such widespread notice. Reviews appeared in The New York Review of Books, The Times Literary Supplement, The New Republic, Newsweek, Time, The Economist, Foreign Affairs, London Review of Books, Book World Washington Post, the Los Angeles Times Book Review, the New York Times Book Review, The Wall Street Journal, The Daily Telegraph, The Sunday Telegraph, The World \& I, Policy Review, Commentary, National Review, The Tablet, and The Spectator. The reviewers in these journals generally expressed amazement that a tragedy of this magnitude was unknown to the wider world and that Conquest's book was the first study of the subject. Some such as Michael Bordeaux, eminent churchman and defender of believers in the Soviet bloc, dealt with the moral dimension of the world's indifference to what he saw as a major genocide. While many reviewers called the tragedy genocide, some questioned whether this term was appropriate, especially if they saw Soviet policies as directed against the peasantry and not against Ukrainians per se. But the project had clearly succeeded in bringing the Famine in Ukraine to a vast audience who had little or no inkling of it.

Appearing in 1986, just as glasnost and perestroika were beginning in the Soviet Union, Harvest of Sorrow posed a major challenge to the Soviets and their supporters in the West. When the Toronto Globe and Mail published two large excerpts from the book (29 November 1986 and 1 December 1986), Yuri Bogayevsky, first secretary at the Soviet embassy in Ottawa, wrote a tortured and convoluted response on 13 December 1986. He insisted that no imposed famine had occurred in 1931-32 (sic), though drought conditions had reduced the harvest. He denied that there was mass starvation and dwelled on kulak sabotage in disorganizing agriculture. He asserted that Ukraine's population has remained stable in 1932 and 1933 (32 million) and concluded: "True, times were hard and many people did suffer, especially those families whose fathers, sons, and brothers were murdered by Kulaks. But not nearly to the extent portrayed in less than scholarly publications" (Bogayevsky). Conquest answered this lame response in spirited form in the 10 January 1987 issue ("A drought in Ukraine"). The degree of Soviet consternation over the campaign to promote awareness of the Ukrainian Famine in the West, and Conquest's book in particular, could be seen in the publication of a monograph titled Fraud, Famine and Fascism. The Ukrainian Genocide Myth from Hitler to Harvard in 1987 (pages 85-90 deal with Conquest's book). Ostensibly 
written by Douglas Tottle, a Canadian labour journalist and Communist Party member, the book was likely compiled in the Soviet Union. Certainly its sources, including citations from Ukrainian materials, and its tone of discourse pointed to composition in Kyiv. Reflecting the increasingly untenable nature of the Soviet position on the Famine, the Ukrainian Canadian Communist Kobzar Publishing House had refused the demand of the Communist Party of Canada that it publish the volume. Leading Ukrainian Canadian Communist Peter Krawchuk maintained that the book came recommended by Yurii Kondufor, director of the Institute of History of the Academy of Sciences of the Ukrainian SSR, Academician Arnold Shlepakov, director of the Institute of Social and Economic Problems in Foreign Countries, and Vasyl' Yurchuk, director of the Institute of Party History, a list that, along with the type of research materials presented, points to the book's probable origin (Krawchuk 250).

Scholars of Russian and East European history and Soviet studies and population specialists wrote many of the reviews in general publications (Alec Nove, Geoffrey Hosking, Paul Robert Magocsi, Bruce Lincoln, J. Arch Getty, Peter Wiles, Herbert Ellison) as well as in the more usual academic journals (John A. Armstrong, George Liber, Henry Huttenbach, R. H. Johnston, Stefan Merl, J. Bilocerkowycz, R. E. Johnson, Peter Kenez, Vladimir Brovkin, Gordon B. Smith, L. A. Kosiński, H. Hunter). Academics, when writing for broader publics, were more likely to be frank in expressing their reactions. The eminent historian of Russia, Geoffrey Hosking, exclaimed in the Times Literary Supplement:

\footnotetext{
Almost unbelievably, Dr. Conquest's book is the first historical study of what must count as one of the greatest man-made horrors in a century particularly full of them. E. H. Carr used to assert that the history of the Soviet Union after about 1930 probably could not be adequately written, because of the paucity of reliable sources. I had always assumed that this warning applied particularly to the collectivization and especially to the famine; it therefore comes as a shock to discover just how much material has accumulated over the years, most of it perfectly accessible in British libraries..., [and] we are all in Conquest's debt for making coherent what had previously been known in an uncertain and fragmentary way.
}

Writing in The New York Review of Books, the renowned economist and Sovietologist Peter Wiles declared,

Robert Conquest is one of those rare gifted beings who can combine in one book the results of research, documented and footnotes, with the haute vulgarisation thereof. So The Harvest of Sorrow is a very good book 'in both kinds'-and let no mere academic say which is more honorable. 
He went on to admit that he had always had difficulty in dealing with works such as The Black Deeds of the Kremlin, two volumes featuring survivor testimonies published in 1953-55: "I must confess that the title of that book has always put me off from reading it, but it is not the least of Conquest's merits to have ploughed ahead." In this he was joined by Hosking who said: "Western scholars have been inclined to pass snootily by compilations with such lurid titles. But they were wrong; such records represent "popular history' in a way that ought to appeal to every reader of Annales." Wiles asserted that Conquest had espoused the Ukrainian exile view of the Famine and had convinced the reviewer of it. He, like Hosking, accepted the intentionality of the Famine against Ukrainians.

Hosking's and Wiles' reviews reflected the power of Conquest's exposition of what was largely a terra incognita, even among specialists of the Soviet Union. Even the sharpest critics of Conquest's book testified to the paucity of scholarly literature. ${ }^{2}$ From those who fully accepted Conquest's conclusions to those who rejected major parts of his explanation, scholars grappled with numerous issues raised in the book. Hosking and Wiles had affirmed Conquest's use of survivor testimony, while others were more sceptical of its use as a source. Many reviewers addressed demographic issues, i.e., Conquest's estimate of 5 million deaths in Ukraine and 2 million elsewhere. The noted economist Alec Nove estimated more than 5 million total deaths and saw 7 million in the realm of possibility. Others saw Conquest's estimates as too high. Some questioned his competence and his failure to utilize fully the discussions of $\mathrm{S}$. Rosefielde, S. G. Wheatcroft, R. W. Davis, Barbara Andersen, and Brian Silver on the pages of Soviet Studies and Slavic Review in the 1980s. ${ }^{3}$ Some

\footnotetext{
2 Stefan Merl, "Entfachte," p. 569 says it had attracted "incredibly little attention" outside of Ukrainian exile literature.

3 Rosefielde 1980 initiated the discussion. For the other side, see Davies and Wheatcroft 1980 and two articles by Wheatcroft 1981 and 1983. More direct attention to population statistics resulted in further debate that came to be focused more frequently on the Famine: cf. Rosefielde 1983 and 1984; Wheatcroft 1984; Rosefielde 1985; Wheatcroft 1985; also see Anderson and Silver 1985. The latter two authors mention a publication on the Ukrainian Famine to which Mace, Conquest and Dalrymple contributed. This may be seen as an outcome of the Harvard Famine Project, and it discusses the new attention given to the Ukrainian Famine (cf. Anderson and Silver 1985, 518, 532-34). The Slavic Review (45.2 [Summer 1986] then published a compendium titled "Ongoing Discussion," which included letters and rejoinders by Robert Conquest, Stephen Cohen, Stephen G.
} 
scholars such as Peter Wiles accepted Conquest's thesis that the origins of the 1932-33 Famine, unlike the Kazakh Famine, could not be found in collectivization. A number of reviewers questioned whether the Famine had been intentional. Others believed that it could not be seen as directed against Ukraine and Ukrainians. The applicability of the term "genocide" was discussed in both general interest and scholarly publications, accepted by many reviewers and contested by others.

Broad as the discussion was, it was not universal, nor always inspiring. Perhaps because so many scholars were writing for wide circulation publications (or because of the book-dispatching policy of the presses), reviews did not appear in some of the most significant professional journals (Slavic Review, Soviet Studies, Russian Review, and Slavonic and East European Review). The book also became a casus belli for some of the revisionist historians, who saw Conquest as a proponent of the totalitarian school, rightist politics, and Ukrainian nationalism. The review by J. Arch Getty in London Review of Books may be seen as such an engaged polemical piece. He opined:

Conquest's hypothesis, sources and evidence are not new. Indeed, he himself first put forward his view two years ago in a work sponsored by the American Enterprise Institute. The intentional famine story, however, has been an article of faith for Ukrainian émigrés in the West since the Cold War. Much of Conquest's most graphic description is taken from such period-pieces as The Golgotha of Ukraine (1953), The Black Deeds of the Kremlin (1953), and Communism is the Enemy of Mankind (1955). Conquest's book will thus give a certain academic credibility to a theory which has not been generally accepted by non-partisan scholars outside the circles of exiled nationalities. In today's conservative political climate, with its 'evil empire' discourse, I am sure the book will be very popular. ("Starving the Ukraine")

Among Conquest's transgressions were that he "even uses Ukrainian placenames rather than their more standardized Russian versions." Getty maintained, "scholars are obliged to eschew polemic in favour of balanced analysis." Yet for Getty and some of his cohort, balance was difficult to achieve. Some of the most intemperate comments were quoted in a politically partisan piece on the Ukrainian Famine in the Village Voice. Roberta Manning of Boston College, described by author Jeff Coplon as a

Wheatcroft, Steven Rosefielde, Barbara Anderson and Brian Silver (295-313). 
"veteran Sovietologist," is quoted as saying about Conquest: "He's terrible at doing research... He misuses sources, he twists everything" (Coplon 32).

The reception of Conquest's book in 1986-88 could serve as the centerpiece for an examination of the state of the study of Soviet history in the West in the 1980s. But momentous events were quickly overtaking both the Soviet Union and academia. Within a few years, the Soviet Union was no more, scholars from that region could fully take part in international discussions, a wider public there could voice its views, and archives were opened. The emergence of an independent Ukrainian state created a new context for examining the Ukrainian Famine, and thousands and thousands of survivors' testimonies were published. The Soviet denials that a famine or mass deaths had occurred disappeared in the last stages of glasnost. Interpretations could still differ, especially between scholars in Ukraine and Russia, but the internationalization of the study of the Famine to include scholars in these two countries transformed the field. Demographers finally had access to sources that have led to estimates by Oleh Wolowyna and his colleagues of 4 million direct deaths in Ukraine, making Conquest's estimates quite respectable. 4

We cannot know what would have happened to the academic Ukrainian Famine discussion in the West had the momentous changes not occurred. We can see however that the 1980s marked a watershed in establishing the academic study of the Ukrainian Famine, which since the late 1980s has increasingly been called the Holodomor. The literature on the Holodomor has grown greatly over that period.

Since 1998 when Dr. James Mace inaugurated the series, an Annual Ukrainian Famine Lecture has been held at the University of Toronto. For the seventy-fifth anniversary of the Ukrainian Famine, the Toronto Office of the Canadian Institute of Ukrainian Studies, the University of Alberta; the Petro Jacyk Program for the Study of Modern Ukraine of the Centre for European, Russian, and Eurasian Studies of the University of Toronto; and the Ukrainian Canadian Research and Documentation Centre of Toronto held a conference featuring research and archives from Ukraine and Russia. This conference demonstrated to what degree the study of the Holodomor now emanated from the former Soviet Union. These papers were published as The Holodomor of 1932-33. Papers from the 75th Anniversary Conference on the Ukrainian Famine-Genocide, University of Toronto, November 1, 2007.

4 Wolowyna gave the figure in a lecture, "Demographic Complexity of the Holodomor: Beyond the controversy on the Number of Losses," on 24 November 2014, held at the Canadian Institute of Ukrainian Studies in Edmonton. 
In planning for the eightieth anniversary, the organizers, which now included the Holodomor Research and Educational Consortium (established in 2013 at the Canadian Institute of Ukrainian Studies though the support of the Temerty Family Foundation) and the St. Vladimir Institute, decided that it was appropriate to consider what the last thirty years of research on the Holodomor had meant for understanding topics such as Ukrainian history, Soviet history, genocide studies, Stalinism, and the history of the Communist Party. The conference "Contextualizing the Holodomor: A Conference on the $80^{\text {th }}$ Anniversary" was held at the University of Toronto on September 27-28, 2013, with the support of the Canadian Foundation for Ukrainian Studies, the Ukrainian Canadian Congress, Toronto branch, and the Ukrainian Studies Fund. Each of the major presenters, Olga Andriewsky, Trent University; Andrea Graziosi, University of Naples Federico II; Françoise Thom, Paris-Sorbonne University (Paris IV); Norman Naimark, Stanford University; and Stanislav Kul'chyts'kyi, Institute of History, Academy of Sciences of Ukraine, addressed the significance of the study of the Holodomor for the examination of one or more of the broader topics. Discussants for the papers were Serhii Plokhy, Harvard University; David Marples, the University of Alberta; Mark von Hagen, Arizona State University; Douglas Irwin, Rutgers University; and Liudmyla Hrynevych, Institute of the History of Ukraine, National Academy of Sciences of Ukraine. The conference concluded with remarks on the Holodomor by Roman Serbyn, professor emeritus of Université du Québec à Montréal, who received an award from the Ukrainian Canadian Congress for his many years of research and encouraging study on the Holodomor. The presentations at the conference were accompanied by wide-ranging discussions. The full conference and discussions may be accessed at the website <www.holodomor.ca>.

We are grateful to Oleh S. Ilnytzkyj, editor of the online East/West: Journal of Ukrainian Studies for publishing the major presentations of the conference. They will also appear in print form from the Holodomor Research and Education Consortium (HREC), distributed by Canadian Institute of Ukrainian Studies Press. Andrij Makuch, associate director of research of HREC, undertook the editing of the contributions, with the assistance of Oleh S. Ilnytzkyj.

\section{Works Cited}

Anderson, Barbara A. and Brian Silver. "Demographic Analysis and Population Catastrophes in the USSR." Slavic Review 44.3 (Autumn 1985): 517-36. Print. 
---. "Tautologies in the Study of Excess Mortality in the USSR in the 1930s." Slavic Review, 45.2 (Summer, 1986): 307-13. Print.

Bogayevsky, Yuri. "Kulaks Killed Best Workers in Ukraine." The Globe and Mail 13 Dec. 1986: D7. Print.

Conquest, Robert. “A Drought in Ukraine.” The Globe and Mail 10 Jan. 1987: N.pg. Print.

Conquest, Robert, Stephen Cohen and Stephen G. Wheatcroft. [New Demographic Evidence on Excess Collectivization Deaths: Further Comments on Wheatcroft, Rosefielde, Anderson and Silver]. Letter. Slavic Review 45.2 (Summer 1986): 295-299. Print.

Coplon, Jeff. "In Search of a Soviet Holocaust: a 55-Year-Old Famine Feeds the Right." The Village Voice 12 Jan. 1988: 32. Print.

Davies, R. W. and S. G. Wheatcroft. "Steven Rosefielde's Kliukva." Slavic Review 39.4 (Dec. 1980): 593-602. Print.

Getty, J. Arch. "Starving the Ukraine. The Harvest of Sorrow: Soviet Collectivization and the Terror-Famine by Robert Conquest." London Review of Books 9.2 (22 Jan. 1987): 7-8. Print.

The Holodomor of 1932-33. Papers from the 75th Anniversary Conference on the Ukrainian Famine-Genocide, University of Toronto, November 1, 2007. Spec. issue of The Harriman Review 16.2 (November 2008). Print.

Hosking, Geoffrey, "Arranging a Catastrophe. Harvest of Sorrow: Soviet Collectivization and the Terror-Famine by Robert Conquest." TLS - The Times Literary Supplement 4377 (20 Feb. 1987): 191. Print.

Khmil', Ivan. "Shche odna ialova korova. Pro ideiu stvorennia v Ukraini 'Instytutu Henotsydu.'” Demokratychna Ukraina 12 Feb. 1994: N.pg. Print.

Kohut, Zenon E. and Olga A. Andriewsky. "Shaping Ukrainian Studies: A Portrait of Frank E. Sysyn." Tentorium Honorum: Essays Presented to Frank E. Sysyn on his Sixtieth Birthday. Ed. Olga Andriewsky et al. Edmonton-Toronto: Canadian Institute of Ukrainian Studies Press, 2010. 1-30. Print.

Krawchuk, Peter. Our History: The Ukrainian Labour-Farmer Movement in Canada 1907-1991. Toronto: Lugus, 1996. Print.

Mace, James E. “Famine and Nationalism in Soviet Ukraine." Problems of Communism May-June 1984: 37-50. Print.

The Man-Made Famine in Ukraine: Robert Conquest, Dana Darymple, James Mace, Michael Novak. Washington, D.C.: American Enterprise Institute for Public Policy Research, 1984. Print.

Merl, Stephan. "Entfachte Stalin die Hungersnot von 1932-1933 zur Auslöschung des ukrainischen Nationalismus? Anmerkungen $\mathrm{zu}$ neueren westlichen Veröffentlichungen über die "ukrainische" Hungersnot." Jahrbücher für Geschichte Osteuropas 37.4 (1989): 569-90. Print.

Procyk, Oksana, Leonid Heretz and James E. Mace. Famine in the Soviet Ukraine 1932-1933: A Memorial Exhibition. Widener Library Harvard University. Cambridge, MA: Distributed by Harvard UP for Harvard College Library, 1986. Print.

Rosefielde, Steven. "Demographic Analysis and Population Catastrophes in the USSR: A Rejoinder to Barbara Anderson and Brian Silver." Slavic Review 45.2 (Summer 1986): 300-06. Print. 
---. “Excess Collectivization Deaths, 1929-1933: New Demographic Evidence." Slavic Review 43.1 (Spring 1984): 83-88. Print.

---. "Excess Mortality in the Soviet Union: a Reconsideration of the Demographic Consequences of Forced Industrialization, 1929-1949." Soviet Studies 35.3 (Jul. 1983): 385-409. Print.

---. "New Demographic Evidence on Collectivization Deaths: a Rejoinder to Stephen Wheatcroft." Slavic Review 44.3 (Autumn 1985): 509-16. Print.

---. "The First 'Great Leap Forward."” Slavic Review 39.4 (Dec. 1980): 559-82. Print. Serbyn, Roman and Bohdan Krawchenko, eds. Famine in Ukraine, 1932-1933. Edmonton: Canadian Institute of Ukrainian Studies, 1986. Print.

Silver Brian. "Tautologies in the Study of Excess Mortality in the USSR in the 1930s." Slavic Review 45.2 (Summer 1986): 307-13. Print.

Sysyn, Frank E. "The Ukrainian Famine of 1932-33: The Role of the Ukrainian Diaspora in Research and Public Discussion." Studies in Comparative Genocide. Ed. Levron Chorbajian and George Shirinian. New York and London: St. Martin's and Macmillan Press, 1999. 182-215. Print.

Tottle, Douglas. Fraud, Famine and Fascism. The Ukrainian Genocide Myth from Hitler to Harvard. Toronto: Progress Publishers, 1987. Print.

Wheatcroft, Stephen. G. "A Note on S. Rosefielde's Calculations of Excess Mortality in the USSR, 1929-1949." Soviet Studies 36.2 (Apr. 1984): 277-81. Print.

---. "Towards a Thorough Analysis of Soviet Forced Labour Statistics." Soviet Studies 35.2 (Apr. 1983): 223-32. Print.

---. "On Assessing the Size of Forced Concentration Labour in the Soviet Union, 1929-1956." Soviet Studies 33.2 (Apr. 1981): 265-95. Print.

Wiles, Peter. "The Harvest of Sorrow: Soviet Collectivization and the Terror-Famine by Robert Conquest." New York Review of Books 34.5 (26 Mar. 1987): 43-45. Print.

\section{Reviews of Harvest of Sorrow}

Armstrong, J. A. "The Harvest of Sorrow: Soviet Collectivization and the TerrorFamine by Robert Conquest." American Historical Review 92.5 (1987): 1240-41. Print.

Balan, Jars. "History of Horror Keeps Objectivity." Edmonton Journal 20 Dec. 1986: F4. Print.

Balan, Jars. "Tottle Review Unscrupulous Twaddle." Letter. Canadian Dimension 1987: 2, 46. Print.

Best, Paul J. "The Harvest of Sorrow: Soviet Collectivization and the Terror Famine by Robert Conquest." The Polish Review 35.3/4 (1990): 185-88. Print.

Bilocerkowycz, J. "The Harvest of Sorrow: Soviet Collectivization and the TerrorFamine by Robert Conquest." Problems of Communism 38.4 (1989): 133-40. Print.

Blake, Patricia. "Books: The War Against the Peasants the Harvest of Sorrow by Robert Conquest." Time 8 Dec. 1986: 91-92. Print.

Booker, Christopher. "A Mad Avalanche of Evil. The Harvest of Sorrow: Soviet Collectivization and the Terror-Famine by Robert Conquest." The Spectator 25 Oct. 1986: 32-34. Print. 
Bourdeaux, Michael. "The Harvest of Sorrow: Soviet Collectivization and the TerrorFamine by Robert Conquest." Church Times 21 Nov. 1986: 6. Print.

Brovkin, Vladimir N. "Robert Conquest's Harvest of Sorrow: a Challenge to the Revisionists." Harvard Ukrainian Studies 11.1/2 (June 1987): 234-45. Print.

Campbell, John C. "The Harvest of Sorrow: Soviet Collectivization and the TerrorFamine by Robert Conquest. Famine in the Ukraine, 1932-1933." Ed. Roman Serbyn and Bohdan Krawchenko. Foreign Affairs 65.4 (Spring, 1987): 908. Print.

Conquest, Robert. "Harvest of Sorrow.” Letter. The New Republic 1 Dec. 1986: 3. Print.

Conquest, Robert. Reply to Letter of J. Arch Getty. London Review of Books 9.97 May 1987. http://www.lrb.co.uk/v09/n02/j-arch-getty/starving-the-ukraine. Web.

Conquest, Robert. Reply to Letter of J. Arch Getty. London Review of Books 9.17. 1 Oct. 1987. http://www.lrb.co.uk/v09/n02/j-arch-getty/starving-the-ukraine. Web.

"Conquest's "Harvest of Sorrow": an Overview of the Reviews." The Ukrainian Weekly 25 Jan. 1987. 5, 12. Print.

Davies, R. W. "Reviews: The Harvest of Sorrow: Soviet Collectivization and the Terror-Famine by Robert Conquest." Detente 9/10 (1987): 44-45. Print.

Ellison, Herbert J. "Harvest of Sorrow: Soviet Collectivization and the Terror-Famine by Robert Conquest." The Los Angeles Times 19 Nov. 1986: 1-2. Print.

Ennew, C. "The Harvest of Sorrow: Soviet Collectivization and the Terror-Famine by Robert Conquest." Journal of Agricultural Economics 38.3 (1987): 521-22. Print.

Floyd, David. "Man-made famine." The Daily Telegraph 12 Sep. 1986. N.pg. Print.

"Genocide in the Ukraine." The Economist 11 Oct. 1986: 104. Print.

Getty, J. Arch. "Starving the Ukraine. The Harvest of Sorrow: Soviet Collectivization and the Terror-Famine by Robert Conquest." London Review of Books 9.2 (22 Jan. 1987): 7-8. Print. [See also letters between Robert Conquest and J. Arch Getty.]

Getty, J. Arch. Reply to Letter of Robert Conquest. London Review of Books 9.1021 May 1987. http://www.lrb.co.uk/v09/n02/j-arch-getty/starving-the-ukraine. Web.

Getty, J. Arch. Reply to Letter of Robert Conquest. London Review of Books 9.1920 Oct. 1987. http://www.Irb.co.uk/v09/n02/j-arch-getty/starving-the-ukraine. Web.

Goodman, Walter. "Putting Pieces Together For Soviet Famine Book. Scholar Studies "Things I Want To Know About."' The New York Times 15 Oct. 1986. 86D. Print.

Gross, John. "Review of the Harvest of Sorrow." The New York Times 7 Oct. 1986: C17. Print.

"The Harvest of Sorrow: Soviet Collectivization and the Terror-Famine by Robert Conquest." The Wilson Quarterly 11.1 (1987): 155-6. Print.

Heller, M. "The Harvest of Sorrow: Soviet Collectivization and the Terror-Famine by Robert Conquest." Quinzaine Litteraire 479 (1987): 23. Print.

Hillier, Bevis. "'Harvest' of Soviet Terrorism Reaped by Historian Conquest." The Los Angeles Times 19 Nov. 1986: 1-2. Print. 
Hosking, Geoffrey, "Arranging a Catastrophe. Harvest of Sorrow: Soviet Collectivization and the Terror-Famine by Robert Conquest." TLS - The Times Literary Supplement 4377 (20 Feb. 1987): 191. Print.

Hunter, Holland. "The Harvest of Sorrow: Soviet Collectivization and the TerrorFamine by Robert Conquest." Annals of the American Academy of Political and Social Science 496 (March 1988): 152. Print.

Huttenbach, Henry. "The Harvest of Sorrow: Soviet Collectivization and the TerrorFamine by Robert Conquest." Martyrdom and Resistance 13.4 (March-April 1987): 1, 10. Print.

Johnson, R. E. "The Harvest of Sorrow: Soviet Collectivization and the Terror-Famine by Robert Conquest." Labour / Le Travail 23 (1989): 379-81. Print.

Johnston, R. H. "Robert Conquest. The Harvest of Sorrow: Soviet Collectivization and the Terror-Famine." Canadian Slavonic Papers / Revue Canadienne Des Slavistes 29.2/3 (June-September 1987): 348-49. Print.

Kenez, Peter. "The Harvest of Sorrow: Soviet Collectivization and the Terror-Famine by Robert Conquest." Society 25.3 (1988): 94-96. Print.

Kosiński, L. A. "The Harvest of Sorrow: Soviet Collectivization and the TerrorFamine by Robert Conquest." Population and Development Review 13.1 (March 1987): 149-53. Print.

Lawrence, John. "Ukrainian Genocide." The Tablet 1 Nov. 1986: 4. Print.

Liber, George. "The Harvest of Sorrow: Soviet Collectivization and the TerrorFamine by Robert Conquest." Political Science Quarterly 103.2 (1988): 400-01. Print.

Lieven, Anatol. "Ukrainian Genocide." The Tablet 22 Nov. 1986. http://archive.thetablet.co.uk/article/22nd-november-1986/14/ukrainiangenocide. Web.

Lincoln, Bruce. "Russia's Grim Famine History.” The World \& I Apr. 1987: 424-30. Print.

Magocsi, Paul Robert. "Famine or Genocide." The World \& I Apr. 1987: 416-23. Print.

Meissner, Frank. "The high price of Soviet agricultural collectivization: The Harvest of Sorrow: Soviet Collectivization and the Terror-Famine by Robert Conquest." Food Policy 12.4 1987: 403-05. Print.

Merl, Stephan. "Entfachte Stalin die Hungersnot von 1932-1933 zur Auslöschung des ukrainischen Nationalismus? Anmerkungen $\mathrm{zu}$ neueren westlichen Veröffentlichungen über die "ukrainische" Hungersnot." Jahrbücher für Geschichte Osteuropas 37.4 (1989): 569-90. Print.

---. "Wie viele Opfer forderte die "Liquidierung der Kulaken als Klasse"? Anmerkungen zu einem Buch von Robert Conquest." Geschichte und Gesellschaft 14.4 (1988): 534-40. Web.

Methvin, Eugene H. "The Other Holocaust.” National Review 39.328 Feb. 1987: 4849. Print.

Miller, Jim. "The Grim Hunger." Newsweek 17 Nov. 1986: 95. Print.

Mount, Ferdinand. "Ruling Through Famine." The Sunday Telegraph 28 Sep. 1986: 14. Print.

Neilson, K. "The Harvest of Sorrow: Soviet Collectivization and the Terror-Famine by Robert Conquest." Queens Quarterly 5.1 (1988): 193-96. Print. 
Nove, Alec. "When the Head Is Off...The Harvest of Sorrow: Soviet Collectivization and the Terror-Famine by Robert Conquest." The New Republic 195.18 (3 Nov. 1986): 34-7. Print.

Prager, Dennis. “The moral riddle of our time. Why don't all good people hate Communism?" Ultimate Issues 2.4 (Fall 1986): 1-6. Print.

Puddington, Arch. "The Harvest of Sorrow: Soviet Collectivization and the TerrorFamine by Robert Conquest." Commentary 83.6 (1 Jun. 1987): 74-7. Print. Robert Conquest." Queens Quarterly 5.1 (1988): 193-96. Print.

Salisbury, Arnold. "The Ukrainian Holocaust Documented." Global Affairs (Spring 1987): N.pg. Print.

---. "The Ukrainian Holocaust Documented." The New York City Tribune 20 Apr. 1987: N.pg. Print.

Shannon, William V. "The wounds from the past that thwart Gorbachev's reform plans." The Boston Globe 11 Feb. 1987: 15. Print.

Simes, Dmitri K. "Stalin and His War Against the Peasantry." Book World; The Washington Post 16.42 (19 Oct. 1986): 3, 14. Print.

Smith, Gordon. B. "The Harvest of Sorrow: Soviet Collectivization and the TerrorFamine by Robert Conquest." The Journal of Politics 49.3 (August 1987): 90405. Print.

Sorokowski, Andrew. “Ukrainian Genocide.” The Tablet 6 Dec. 1986: 12. Print.

"Terror beyond belief. Robert Conquest on how Soviet and Western experts are coming to terms with the extent of Stalin's purges." The Independent 12 May 1988: N.pg. Print.

Thomas, K. T. "The Harvest of Sorrow: Soviet Collectivization and the Terror-Famine by Robert Conquest." Radical History Review 52 (1992): 121-31. Print.

Tottle, Douglas. "The Realm of Subjectivity." Canadian Dimension March 1987: 3637. Print.

Warren, Spencer. "The Harvest of Sorrow: Soviet Collectivization and the TerrorFamine by Robert Conquest." Policy Review 39 (1987): 84-5. Print.

Whitney, Craig. "The Harvest of Sorrow: Soviet Collectivization and the TerrorFamine by Robert Conquest." The New York Times Book Review 26 Oct. 1986: 11-12. Print.

Wiles, Peter. "The Harvest of Sorrow: Soviet Collectivization and the Terror-Famine by Robert Conquest." New York Review of Books 34.5 (26 Mar. 1987): 43-45. Print.

Will, George F. “Stalin's Right-Hand Man.” The Washington Post 16 Nov. 1986: K7. Print.

“Zhnyva Pechali.” Ukrains'ki visti (Detroit) 23 Nov. 1986: 2-4. Print. 